\title{
Hogyan változtak a koleszterinszintek az elmúlt 20 év alatt egy Békés megyei községben?
}

\author{
Márk László dr. ${ }^{1}$ - Hanyecz Vince dr. ${ }^{2}$ \\ ${ }^{1}$ Békés Megyei Pándy Kálmán Kórház, II. Belgyógyászat-Kardiológia, Gyula \\ ${ }^{2}$ Háziorvosi Rendelő, Méhkerék
}

\begin{abstract}
Bevezetés: Kevés adat ismert arról, hogy Magyarországon az elmúlt évtizedekben népességi szinten hogyan változtak a koleszterinszintek. Célkitüzés: A Békés megyei Méhkerék község lakossága körében a szérumkoleszterin-szint öszszehasonlítása a 20 évvel ezelőtti adatokkal. Módszer: A szerzők a Békés megyei Méhkerék községben 1994-ben 778 fơnél végzett szűrővizsgálat során mért szérumkoleszterin-értékeket 20 év elteltével 392, véletlenszerűen kiválasztott, nemben és életkorban illesztett egyén eredményeivel hasonlították össze a családorvosi adatbázis felhasználásá-

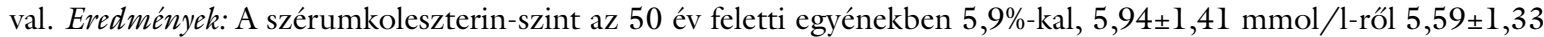
mmol/l-re csökkent $(\mathrm{p} \leq 0,01)$, míg az 50 évnél fiatalabb egyéneknél nem volt szignifikáns változás. Következtetések: Az 50 év felettieknél tapasztalt szérumkoleszterinszint-csökkenés az átfogóbb, szélesebb körben alkalmazott lipidcsökkentő terápia következménye lehet. Az a tény, hogy az 50 év alattiaknál nem volt változás, arra figyelmeztet, hogy a fiatalok esetében a primer prevenció elveit (diéta, rendszeres testmozgás) következetesebben kellene alkalmazni, és - ahol az ajánlások megkövetelik - nem szabad idegenkedni a megfelelő gyógyszeres kezeléstől sem. Orv. Hetil., $2015,156(40), 1614-1617$.
\end{abstract}

Kulcsszavak: koleszterin, kockázati tényező, prevenció, szűrővizsgálat

\section{How did cholesterol levels change in a village in Békés County, Hungary, during the last 20 years?}

Introduction: There are only limited data about the change of cholesterol levels at population level in Hungary. Aim: The aim of the authors was to compare current serum cholesterol levels to those measured 20 years ago in residents of a village in Békés County, Hungary. Method: Using a database of a general ptactitioner, serum cholesterol levels of 778 persons who participated in a screening program in 1994 in the village Méhkerék in Békés County were compared to those obtained 20 years later from 392 randomly selected persons matching age and gender. Results: The serum total cholesterol level of persons over 50 years was decreased by $5.9 \%$, from $5.94 \pm 1.41$ to $5.59 \pm 1.33 \mathrm{mmol} / \mathrm{L}$ $(\mathrm{p} \leq 0.01)$, while it remained unchanged in persons younger than 50 years of age. Conclusions: The decrease of serum cholesterol level observed in patients over 50 years of age can be a consequence of the widely used lipid lowering medication. The lack of change in persons below 50 years of age draws the attention that principles of primary prevention (diet, regular physical activity) should be used more consistently, and medical therapy should be applied when it is recommended by the guidelines.

Keywords: cholesterol, risk factors, prevention, screening

Mark, L., Hanyecz, V. [How did cholesterol levels change in a village in Békés County, Hungary, during the last 20 years?]. Orv. Hetil., 2015, 156(40), 1614-1617.

(Beérkezett: 2015. július 13.; elfogadva: 2015. augusztus 6.) 
Az utóbbi évtizedek kedvező változásai ellenére az atherosclerosissal kapcsolatos betegségek maradtak a halálozási statisztikák listavezetői. Azokban az országokban, ahol az 1970-es, 1980-as években felismerték a megelőzés fontosságát és el is kezdtek tenni érte, megkezdődött a cardiovascularis halálozás csökkenése.

Az Amerikai Egyesült Államokban az ezredfordulón 10 év alatt 30\%-kal csökkent a cardiovascularis okból bekövetkezett halálesetek száma, és ennek hátterében igen nagy súllyal állhat a kockázati tényezők (magas szérumkoleszterin-szint, hypertonia, dohányzás) egyre jobb kontrollja, aminek lényeges eleme a mind hatékonyabb gyógyszerek széles körü alkalmazása [1]. A születéskor várható élettartam 1970 és 2000 között további 6,0 évvel nőtt, amiből 3,9 év a cardiovascularis okból bekövetkezett halálozás csökkenésének volt tulajdonítható. Lenfant az Amerikai Egyesült Államok National Heart, Lung, and Blood Institute vezetőjeként 2003-ban úgy értékelte, hogy a legújabb egészségügyi kutatási eredmények nehezen mennek át a mindennapokba, amikor azokat az orvosi gyakorlatba vagy az emberek egyéni viselkedésébe és a saját egészségükhöz való viszonyuk javításába kellene beilleszteni. A klinikai vizsgálatok által igazolt kedvező lehetőségek kihasználása nem maradéktalan, illetve nagy késedelmet szenved [2]. Laatikainen felmérése szerint a cardiovascularis prevenció szempontjából sikeres európai országnak minősülő Finnországban az 1982 és 1997 közötti 15 éves időszakban 63\%-kal csökkent a cardiovascularis halálozás. Ennek 23\%-a tulajdonítható a kezelés javulásának (reanimáció, fibrinolízis, percutan coronariaintervenció, bypassmútétek), a javulás nagyobb részét (53-72\%) a kockázati tényezők (szérumkoleszterin-szint, hypertonia, dohányzás) megfelelő csökkentésével érték el, és ez utóbbi arányon belül legnagyobb súllyal (37\%) a magas lipidszintek kezelése részesedett [3]. Hasonló arányokról tanúskodik Björck és mtsai svédországi felmérése. 1986 és 2002 között a 2584 éves svéd férfiak ischaemiás szívbetegség miatti halálozása 53,4\%-kal, a nőké 52,0\%-kal csökkent, aminek következtében 2002-ben 13180 fóvel kevesebben haltak meg. A kedvező változás 55\%-a a kockázati tényezők csökkenésének tulajdonítható [4].

A fejlettebb európai országokban és az Amerikai Egyesült Államokban már néhány évtizede tapasztalt javulás epidemiológiai korszakváltásként Magyarországon is megindult. Józan adatai szerint 1993 és 2010 között hazánkban a születéskor várható élettartam 5,33 évvel nőtt, és ebben 2,39 évvel a cardiovascularis halandóság javulása játszott közre [5]. Nincsenek olyan pontos statisztikai adatok, amelyek alapján meghatározható lenne, de a szakértők azt gondolják, hogy az említett közel kétévnyi javulás feléért a lipidszintek kedvező változása, a jobb és hatékonyabb koleszterinszint-csökkentés lehet a felelős.

Ezen számottevő javulás ellenére hazánk cardiovascularis és összhalálozás tekintetében jelentős elmaradást mutat a nyugat-európai adatokhoz viszonyítva. Helis és mtsai 2011-ben elemezték az Európai Unió keleti és nyugati országai, azaz az új és a régi tagállamok halálozási trendjeinek változását és annak okait. A kelet-európai országokban a javulás 20-25 éves késéssel indult meg. A különbségeket a szerzők részben életmódbeli eltérésekkel, részben az invazív vizsgálatokhoz való jobb hozzáféréssel, valamint a hypertonia és a hypercholesterinaemia jobb kezelésével magyarázzák [6].

$\mathrm{Az}$ atherosclerosis és a szérumkoleszterin-szint közötti szoros kapcsolat az 1950-es évek epidemiológiai megfigyelései alapján lett nyilvánvaló, ebben legnagyobb érdeme a Framingham studynak volt. A lipidhipotézis körvonalazódásával megjelentek az első erre ható gyógyszerek is, először a nikotinsav, majd a fibrátok és a gyanták. A statinok megjelenése az 1980-as évek közepére tehető, és a jelenleg is gyakran alkalmazott lipidcsökkentő terápiás paletta eddig utolsó csoportja a koleszterin felszívódását gátlók, amelynek mind ez ideig egyetlen képviselője 2000 után lett hozzáférhető. A lipidcsökkentő terápia egyre gyakrabban került alkalmazásra, de még mindig igen nagy azon betegek aránya, akik nem kapják meg a szükséges, az atherosclerosist megelőző vagy regresszióját okozó, a várható élettartamot bizonyítottan megnyújtó kezelést.

A MULTI GAP vizsgálatsorozat (MULTI Goal Attainment Program) szinte évenkénti gyakorisággal bemutatott eredményei igazolják, hogy ismert érbetegek körében az LDL-koleszterin (LDL-C) szintje jelentősen csökkent $[7,8,9]$.

Nincsen adatunk arra, hogy miként változott hazánkban a koleszterinszint az átlagpopulációban. 1994-ben a Békés megyei Méhkerék községben szűrővizsgálatot végeztünk [10], amelynek keretében kiemelt fontosságot tulajdonítottunk a szérumkoleszterin-szintnek. Jelen vizsgálatunkban összehasonlítjuk a napjainkban mért szérumkoleszterin-szinteket a 20 évvel ezelőtti adatokkal.

\section{Betegek és módszer}

1994-ben szűrővizsgálatot végeztünk az akkor 2400 lakosú Békés megyei községben, Méhkeréken. A vizsgálatban 778 beteg vett részt, az eredményeket a Népegészségügy folyóiratban közöltük [10]. Az akkori és a jelen eredmények összehasonlításához a családorvosi adatbázisból életkorban és nemben illesztett, véletlenszerüen kiválasztott személyek adatait használtuk. A községben több mint három évtizede ugyanaz a háziorvos dolgozik. Az volt a cél, hogy minden korcsoportban a 20 évvel ezelőtti vizsgálat betegszáma felének keressük meg az adatbázisban a 2014. évi szérumkoleszterin-eredményeit. 392 fó adatait dolgoztuk fel. A betegek kor és nem szerinti megoszlását az 1 . táblázat mutatja be. A betegek az adataik felhasználásába beleegyeztek, a vizsgálatot a gyulai Békés Megyei Pándy Kálmán Kórház Intézményi Kutatásetikai Bizottsága jóváhagyta. 
A statisztikai összehasonlítást 2 mintás t-próbával végeztük. Jelen elemzés csak a szérumkoleszterin-szintek összehasonlítását tűzte ki célul, részletesebb, a többi kockázati tényezőt és a jelen terápiát is figyelembe vevő adatfeldolgozást későbbre tervezzük.

\section{Eredmények}

Az 1994-ben vizsgált 778 és a 2014-ben vizsgált 392 beteg életkor-csoportonkénti megoszlása az 1. táblázatban látható. A 2. táblázat a szérumkoleszterin-szintek átlagát mutatja be. Egyik életkorcsoportot nézve sem volt szignifikáns változás 1994 és 2014 között, de ahogy a táblázat utolsó oszlopa mutatja, a fiatalabb korosztályokban inkább magasabbá, az idősekben inkább alacsonyabbá vált a szérumkoleszterin-szint az évek múlásával. A 3. táblázat az 50 évnél fiatalabb és az 50 éves vagy

1. táblázat A vizsgálatban részt vevő betegek korcsoportonkénti száma és neme 1994-ben és 2014-ben

\begin{tabular}{|c|c|c|c|c|c|c|}
\hline \multirow{2}{*}{$\begin{array}{l}\text { Életkor } \\
\text { (év) }\end{array}$} & \multicolumn{3}{|c|}{ Betegszám, 1994} & \multicolumn{3}{|c|}{ Betegszám, 2014} \\
\hline & Férfiak & Nők & Összes & Férfiak & Nők & Összes \\
\hline $18-29$ & 47 & 52 & 99 & 15 & 28 & 43 \\
\hline $30-34$ & 25 & 24 & 49 & 12 & 20 & 32 \\
\hline $35-39$ & 34 & 41 & 75 & 15 & 26 & 41 \\
\hline $40-44$ & 32 & 43 & 75 & 17 & 22 & 39 \\
\hline $45-49$ & 32 & 36 & 68 & 14 & 25 & 39 \\
\hline $50-54$ & 36 & 39 & 75 & 17 & 19 & 36 \\
\hline $55-59$ & 39 & 48 & 87 & 24 & 19 & 43 \\
\hline $60-64$ & 47 & 49 & 96 & 17 & 22 & 39 \\
\hline $65-69$ & 34 & 43 & 77 & 14 & 26 & 40 \\
\hline $70-$ & 35 & 42 & 77 & 16 & 24 & 40 \\
\hline Összesen & 361 & 417 & 778 & 161 & 231 & 392 \\
\hline
\end{tabular}

2. táblázat |Az összkoleszterinszintek változása méhkeréki betegekben életkori csoportok szerint 1994 és 2014 között

\begin{tabular}{|c|c|c|c|c|c|c|c|}
\hline \multirow{2}{*}{$\begin{array}{l}\text { Életkor } \\
\text { (év) }\end{array}$} & \multicolumn{2}{|c|}{1994} & \multicolumn{2}{|c|}{2014} & \multirow[t]{2}{*}{$P$} & \multicolumn{2}{|c|}{ Változás } \\
\hline & $\begin{array}{l}\text { Beteg- } \\
\text { szám }\end{array}$ & $\begin{array}{l}\text { Átlag } \pm \text { SD } \\
(\mathrm{mmol} / \mathrm{l})\end{array}$ & $\begin{array}{l}\text { Beteg- } \\
\text { szám }\end{array}$ & $\begin{array}{l}\text { Átlag } \pm \text { SD } \\
(\mathrm{mmol} / \mathrm{l})\end{array}$ & & $(\mathrm{mmol})$ & $\%$ \\
\hline $18-29$ & 99 & $4,34 \pm 1,10$ & 43 & $4,52 \pm 0,82$ & NS & $+0,18$ & $+4,1$ \\
\hline $30-34$ & 49 & $4,81 \pm 1,26$ & 32 & $5,08 \pm 0,89$ & NS & $+0,27$ & $+5,6$ \\
\hline $35-39$ & 75 & $5,11 \pm 1,26$ & 41 & $5,15 \pm 1,24$ & NS & $+0,40$ & $+7,8$ \\
\hline $40-44$ & 75 & $5,44 \pm 1,09$ & 39 & $5,25 \pm 0,75$ & NS & $-0,19$ & $-3,5$ \\
\hline $45-49$ & 68 & $5,52 \pm 1,41$ & 39 & $5,80 \pm 1,35$ & NS & $+0,28$ & $+5,1$ \\
\hline $50-54$ & 75 & $5,81 \pm 1,40$ & 36 & $5,41 \pm 1,08$ & NS & $-0,40$ & $-6,9$ \\
\hline $55-59$ & 87 & $5,89 \pm 1,23$ & 43 & $5,50 \pm 1,41$ & NS & $-0,39$ & $-6,6$ \\
\hline $60-64$ & 96 & $5,88 \pm 1,18$ & 39 & $5,59 \pm 1,44$ & NS & $-0,29$ & $-4,9$ \\
\hline $65-69$ & 77 & $6,10 \pm 1,70$ & 40 & $5,83 \pm 1,24$ & NS & $-0,27$ & $-4,4$ \\
\hline $70-$ & 77 & $6,04 \pm 1,53$ & 40 & $5,60 \pm 1,45$ & NS & $-0,44$ & $-7,2$ \\
\hline
\end{tabular}

3. táblázat $\mid$ Az összkoleszterinszintek változásának összehasonlítása az 50 év alatti és az 50 éves vagy idősebb betegekben 1994-ben és 2014ben

\begin{tabular}{l|c|c|c|c|c}
\hline \multirow{2}{*}{$\begin{array}{l}\text { Életkor } \\
(\text { év })\end{array}$} & \multicolumn{2}{|c|}{1994} & \multicolumn{2}{|c|}{2014} & \multirow{2}{*}{ P } \\
\cline { 2 - 5 } & $\begin{array}{c}\text { Beteg- } \\
\text { szám }\end{array}$ & $\begin{array}{c}\text { Átlag } \pm \text { SD } \\
(\mathrm{mmol} / \mathrm{l})\end{array}$ & $\begin{array}{c}\text { Beteg- } \\
\text { szám }\end{array}$ & $\begin{array}{c}\text { Átlag } \pm \text { SD } \\
(\mathrm{mmol} / \mathrm{l})\end{array}$ & \\
\hline $18-49$ & 366 & $5,00 \pm 1,28$ & 194 & $5,15 \pm 1,11$ & NS \\
$\geq 50$ & 412 & $5,94 \pm 1,41$ & 198 & $5,59 \pm 1,33$ & $\leq 0,01$ \\
\hline
\end{tabular}

annál idősebb betegek szérumkoleszterin-szintjeit hasonlítja össze. A fiatalabbakban a változás nem volt szignifikáns, ugyanakkor az idősebbekben szignifikánsan alacsonyabbá $(\mathrm{p} \leq 0,01)$ vált a szérumkoleszterin-szint a 20 év alatt $(0,35 \mathrm{mmol} / \mathrm{l}$-es, $5,9 \%$-os csökkenés $)$.

\section{Megbeszélés}

A cardiovascularis morbiditás és mortalitás az utóbbi évtizedekben tapasztalt kedvező változások ellenére továbbra is jelentős népegészségügyi teher és első számú haláloki tényező maradt. Az utóbbi két évtizedben Magyarországon több mint 5 évvel nőtt a születéskor várható élettartam [5]. Ebben jelentős tényezőként szerepelhet az orvosi kezelési módszerek és a gyógyszerek hatékonyságának növekedése, valamint a cardiovascularis prevenció elveinek szélesebb körű alkalmazása is. Ezen megelőzési elvek egyik legfontosabb eleme a lipidcsökkentő kezelés, amelynek elfogadottsága az orvosi körökben, az ismert nehézségek ellenére, egyre növekszik. A statinok alkalmazása elterjedt; 1 mmol/1 LDL-koleszterin-szint-csökkenéssel 10\%-kal tudnánk csökkenteni az összhalálozást, és mintegy 20\%-kal a nagy éresemények gyakoriságát [11]. A gyógyszeres kezelés mellett nagy jelentősége van az egészségtudatos magatartásnak (egészséges életmód, sport, egészséges táplálkozás), aminek szintén kihatásai lehetnek populációs szinten a szérumlipidértékekre és a morbiditásra. Akesson és mtsai több mint 20 ezer svéd férfi 11 éves követésével azt állapították meg, hogy az egészséges életmódra törekvő magatartással 5-ből 4 szívinfarktust meg lehetne előzni [12].

A MULTI GAP vizsgálat 2004 és 2013 között évente mérte fel a lipidszintek alakulását és a célértékek elérését háziorvosok és szakorvosok nagy kockázatú, lipidcsökkentő kezelésben részesülő betegein. A háziorvosok által kezeltekben $1 \mathrm{mmol} / \mathrm{l}$ körüli LDL-koleszterinszintcsökkenést tapasztaltak a 9 éves időszakban [9, 13].

Nem ismerünk olyan hazai közlést, amelyben a lipidszintek változását egy adott közösségen belül vizsgálták volna hosszabb időintervallumban.

$\mathrm{Az}$ Amerikai Egyesült Államokban rendszeresen végzett felmérésben, a NHANES-ben (National Health and Nutrition Examination Survey) is kisfokú csökkenést írtak le az összkoleszterinszintben (5,28-ról 5,15 mmol/l-re), 
ami 40 évnél idősebb férfiakban és 60 évnél idősebb nőkben volt kimutatható [14]. A csökkenést inkább a gyógyszeres kezelésnek tulajdonítják, mint a következetesebb diétázásnak [15, 16].

Vizsgálatunkban az 50 évnél fiatalabbakban nem történt szignifikáns változás a szérumkoleszterin-szintekben az elmúlt 20 év alatt, ugyanakkor az idősebbekben észlelt $0,35 \mathrm{mmol} / \mathrm{l}$-es csökkenés statisztikailag szignifikánsnak bizonyult $(\mathrm{p} \leq 0,01)$. E mögött, az amerikai vizsgálathoz hasonlóan, nagy valószínűséggel inkább a gyakrabban alkalmazott lipidcsökkentő kezelés állhat, mint az egészségtudatosabb életmód.

\section{Következtetések}

Az elmúlt 20 év alatt Méhkerék községben az 50 év felettiekben szignifikánsan csökkent a szérumkoleszterinszint. Ez beleillik a javuló magyar halálozási trendbe. Az, hogy az 50 évnél fiatalabbak koleszterinszintje érdemben nem változott, arra utal, hogy ennek a korosztálynak a kezelésére a jövőben nagyobb figyelmet kell fordítani. A nem manifeszt érbetegség megelőzését ekkor kell elkezdeni. Erősíteni kell a fiatalabbakban is az egészségtudatos magatartásra, a sportolásra, a megfelelő diéta tartására vonatkozó igényt, és azoknál, akiknek a fennálló prevenciós elvek ajánlják, alkalmazni kell a lipidcsökkentőket is.

A tanulmány erőssége, hogy két évtized eltelte után ugyanabban a populációban történt a vizsgálat, ahol ugyanaz a családorvos kezeli a betegeket. Hátránya a kicsi betegszám. A koleszterinszintekkel foglalkozó előzetes eredmények után részletesebb, a társbetegségeket, a többi cardiovascularis kockázati tényezőt és a terápiát is figyelembe vevő elemzés is folyamatban van.

Anyagi támogatás: A cikk megírása anyagi támogatásban nem részesült.

Szerzői munkamegosztás: M. L.: A vizsgálat megtervezése, a kézirat megszövegezése. H. V.: A vizsgálat lefolytatása. A cikk végleges változatát mindkét szerző elolvasta és jóváhagyta.

Érdekeltségek: A szerzőknek nincsenek érdekeltségeik.

\section{Köszönetnyilvánítás}

Ezúton is köszönjük Kondacs András matematikusnak a statisztikai vizsgálatok elvégzésében nyújtott segítségét.

\section{Irodalom}

[1] Myerson, M., Coady, S., Taylor, H., et al.: Declining severity of myocardial infarction from 1987 to 2002: the Atherosclerosis Risk in Communities (ARIC) Study. Circulation, 2009, 119(4), 503-514
[2] Lenfant, C.: Clinical research to clinical practice - Lost in translation? N. Engl. J. Med., 2003, 349(9), 868-874.

[3] Laatikainen, T., Critchley, J., Vartiainen, E., el al.: Explaining the decline in coronary heart disease mortality in Finland between 1982 and 1997. Am. J. Epidemiol., 2005, 162(8), 764773.

[4] Björck, L., Rosengren, A., Bennett, K., et al.: Modelling the decreasing coronary heart disease mortality in Sweden between 1986 and 2002. Eur. Heart J., 2009, 30(9), 1046-1056.

[5] Józan, P.: Change of the political system and epidemiologic transition in Hungary. [Rendszerváltozás és epidemiológiai korszakváltás Magyarországon.] Orv. Hetil., 2012, 153(17), 662-677. [Hungarian]

[6] Helis, E., Augustincic, L., Steiner, S., et al.: Time trends in cardiovascular and all-cause mortality in the 'old' and 'new' European Union countries. Eur. J. Cardiovasc. Prev. Rehabil., 2011, 18(3), 347-359.

[7] Mark, L., Paragh, G., Karadi, I., et al.: An attempt to make lipidlowering therapy more effective in Hungary. The results of MULTI GAP 2010 and the PLUS Program. Arch. Med. Sci., 2011, 7(5), 760-766.

[8] Reiber, I., Paragh, G., Márk, L., et al.: Becoming more "goaloriented" in therapy of dyslipidemias: results of the Hungarian MULTI GAP 2010. [Egyre „célratörôbb” lipidterápiás szokásaink - A Magyar MULTI GAP 2010 eredményei.] Orv. Hetil., 2011, 152(21), 822-827. [Hungarian]

[9] Márk, L., Reiber, I., Paragh, G., et al.: Lipid lowering treatment - MULTI GAP 2012. Treatment adherence and statin persistance. [Lipidcsökkentő kezelés - MULTI GAP 2012. A betegek terápiás együttmúköódése, statin-perzisztencia.] Metabolizmus, 2013, 11(3), 167-172. [Hungarian]

[10] Márk, L., Hanyecz, V., Kondacs, A.: Risk factors of ischaemic heart disease in the population of Békés County. [Békés megyei populáció ischaemiás szívbetegség rizikófaktorainak vizsgálata.] Népegészségügy, 1995, 76(2), 69-74. [Hungarian]

[11] Baigent, C., Blackwell, L., Emberson, J., et al.: Efficacy and safety of more intensive lowering of LDL cholesterol: a meta-analysis of data from 170000 participants in 26 randomised trials. Lancet, 2010, 376(9753), 1670-1681.

[12] Akesson, A., Larsson, S. C., Discacciati, A., et al.: Low-risk diet and lifestyle habits in the primary prevention of myocardial infarction in men: a population-based prospective cohort study. J. Am. Coll. Cardiol., 2014, 64(13), 1299-1306.

[13] Simonyi, G.: Lipid-lowering therapy and patient adherence in the MULTI GAP 2013 trial. [Lipidcsökkentő terápia és betegadherencia a MULTI GAP 2013 vizsgálat tükrében.] Orv. Hetil., 2014, 155(17), 669-675. [Hungarian]

[14] Schober, S. E., Carroll, M. D., Lacher, D. A., et al.: High serum total cholesterol - an indicator for monitoring cholesterol lowering efforts: US adults, 2005-2006. NCHS Data Brief, 2007, 2, $1-8$.

[15] Ford, E. S., Capewell, S.: Trends in total and low-density lipoprotein cholesterol among U.S. adults: contributions of changes in dietary fat intake and use of cholesterol-lowering medications. PLoS ONE, 2013, 8(5), e65228.

[16] Go, A. S., Mozaffarian, D., Roger, V. L., et al.: Executive summary: heart disease and stroke statistics - 2014 update: a report from the American Heart Association. Circulation, 2014, 129(3), $399-410$. 